UDC $621.317 .7(045)$

DOI: $10.18372 / 1990-5548.52 .11868$

I. Yu. Sergeyev

\title{
ANALYSIS OF THE GENERALIZED STRUCTURAL SCHEME OF THE ITERATIVELY INTEGRATING MEASUREMENT CONVERTER
}

Department of Aviation Computer-Integrated Complexes, Educational \& Research Institute of Information and Diagnostic Systems, National Aviation University, Kyiv, Ukraine

E-mail: sergeyevi@i.ua

\begin{abstract}
A significant place among structural methods to increase the accuracy of measuring converters occupy iterative methods of error correction based on a well-developed in mathematics the theory of iterative methods. At the same time, the measurement technique is very widely used various integrating converters, due to their advantages such as high accuracy, noise immunity and sensitivity, simplicity, reliability, low cost, etc. Combining methods of integrating conversion and additive iterative correction of errors has generated a method called by the author iteratively integrating conversion method and devices using this method - iteratively integrating converters. Many of iteratively integrating converters possess high metrological parameters. Generalized structural scheme of the measurement converter which uses iteratively integrating conversion method is described. Analysis of its conversion equation and errors for two cases: first one - where the output value $Y=Y(t)$ is not a constant, while the input values $X, Z 1, Z 2$ are constant and second one - where the input value $X=X(t)$ and output value $Y=Y(t)$ are not constant, while the input values Z1, Z2 are constant, were produced. Basic expressions for the calculation are listed.
\end{abstract}

Index Terms - Generalized structural scheme; iteratively integrating conversion method; conversion equation; integrator; iterative additive correction of errors; dynamics of the iterative process; steady state.

\section{INTRODUCTION}

It is known that among the many methods of increasing the accuracy of measuring converters structural methods are very important [1]. Structural methods of improving the accuracy include use of circuits in which it is possible to eliminate or reduce the influence of some of the errors most unstable blocks and elements for the total error of the device. A significant place among structural methods to increase the accuracy of measuring converters occupy iterative methods of error correction.

Combining methods of integrating conversion and additive iterative correction of errors has generated a method called by the author [2] - [4] iteratively integrating conversion method and devices using this method - iteratively integrating converters (IIC). As known, many of iteratively integrating converters possess high metrological parameters.

Analysis of the generalized structural scheme of iteratively integrating transducers and its conversion equation and errors for the case when the input values $X, Z 1, Z 2$ and output value $Y$ are constant values was made by the author in [5], [6], and for the case where the input variable $X=X(\mathrm{t})$ is not a constant, while the input values $Z 1, Z 2$ and output value $Y$ are constant, was made in the author's previous publication.

\section{PROBLEM STATEMENT}

However, these cases does not fully describe the operation of the converter.

It is of interest to consider the analysis of the generalized structural scheme of iteratively integrating transducers and its conversion equation and errors for the next two cases: first one - where the output value $Y=Y(t)$ is not a constant, while the input values $X$, $Z 1, Z 2$ are constant and second one - where the input value $X=X(t)$ and output value $Y=Y(t)$ are not constant, while the input values $Z 1, Z 2$ are constant.

\section{SOLUTION OF THE PROBLEM}

Generalized structural scheme of IIC described in [2], [5] is shown in Fig. 1.

The input values are $X, Z 1$ and $Z 2$, and the output value $-Y$. The circuit consists of two parts. The first part contains the blocks that perform basic functions: integrator I, sample-and-hold device SH, switches SW1 and SW2 switches. The second part contains auxiliary converters $-\mathrm{CV}_{X}, \mathrm{CV}_{Z 1}, \mathrm{CV}_{Z 2}, \mathrm{CI}_{1}, \mathrm{CI}_{2}$, $\mathrm{CO}_{1}, \mathrm{CO}_{2}, . ., \mathrm{CO}_{m}, \mathrm{BC}$, inverter INV, adder ADD, having transfer coefficients, respectively, $K_{X}, K_{Z 1}$, $K_{\mathrm{Z} 2}, K_{\mathrm{CI} 1}, K_{\mathrm{CI} 2}, K_{\mathrm{CO} 1}, K_{\mathrm{CO} 2}, . ., K_{\mathrm{CO} m}, \beta, K_{\mathrm{INV}}, K_{\mathrm{ADD}}$.

The work of the converter is described in [2].

Case 1. Consider the case where the combination of input and output quantities of the converter under consideration is the following: the output value $Y=Y(\mathrm{t})$ is not a constant, while the input values $X, Z 1, \mathrm{Z} 2$ are constant.

In this case, one of the blocks $\mathrm{C}_{2}, \ldots \mathrm{C}_{n}$ is a controlled generator, i.e. constant-to-variable converter.

Suppose that the inverting transducer BC does not change the shape of the curve of the value $Y(t)$, i.e. it is a scaling converter, and before the start of the conversion, the average value of the output value 
$Y(t)$ is equal to $Y_{\mathrm{OC}}$. Similarly to the way it was done in works [2], [3], [5] and [6], we can write down in this case the expressions for determining the output value $Y(t)$ after the end of the 1 st, 2 nd and $n$th conversion cycles

$$
Y_{1 C}=X K_{X} Z 1 K_{Z 1} \prod_{i=1}^{l} K_{i}+Y_{0 C} Q .
$$

It is assumed that the time interval $Z 2 K_{Z 2}$ is equal to or is a multiple of the period of variation of the output value $Y(t)$.

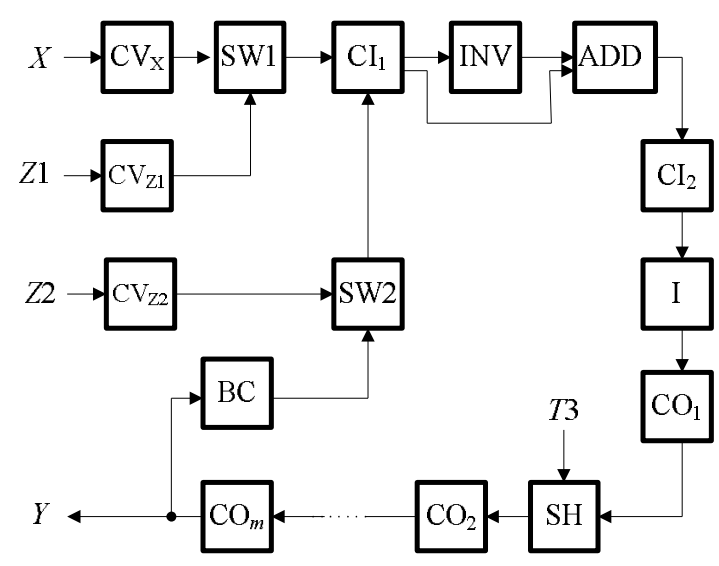

Fig. 1. A generalized structural scheme of iteratively integrating converter

After the end of the $n$th conversion cycle

$$
Y_{n C}=X K_{X} Z 1 K_{Z 1} \prod_{i=1}^{l} K_{i} \sum_{j=1}^{n} Q^{j-1}+Y_{0 C} Q^{n}
$$

or

$$
Y_{n C}=\frac{X K_{X} Z 1 K_{Z !}}{Z 2 K_{Z 2} \beta}\left(1-Q^{n}\right)+Y_{0 C} Q^{n} .
$$

In the steady state

$$
Y_{\infty C}=\frac{K_{X} Z 1 K_{Z !}}{Z 2 K_{Z 2} \beta} X .
$$

It follows that the inverse transformer changes the shape of the curve of the output value $Y(t)$, i.e. it is a measuring transducer, for example, a converter of mean, rms or amplitude values. In this case, for the output value of the inverter, in the steady state, in the same manner as in expression (1), we can write

$$
Y_{\infty \beta}=\frac{K_{X} Z 1 K_{Z !}}{Z 2 K_{Z 2}} X .
$$

The output value of the entire converter under consideration $Y_{\infty a(m, r m s)}$ is related through the transmission factor $\beta_{a(m, r m s)}$ with the output value of the inverse converter $\mathrm{BC} Y_{\infty \beta}$.

$$
Y_{\infty a(m, r m s)}=\frac{Y_{\infty \beta}}{\beta_{a(m, r m s)}}=\frac{K_{X} Z 1 K_{Z !}}{\beta_{a(m, r m s)} Z 2 K_{Z 2}} X,
$$

where the subscript a, $m$ or $r m s$ for output value $Y(t)$ indicates the amplitude, mean or $r m s$, respectively value, of the output $Y(t)$. Thus, on the left-hand side of equation (2) we have the amplitude, mean or $r m s$ value of the output value $Y(t)$, depending on whether the converter - amplitude, mean or $r m s$ values - is the inverse converter $\mathrm{BC}$.

From the expressions (1) and (2) it can be concluded that the converter under consideration can be used as a precision controlled generator.

In this case, the input value of the converter under consideration can be any of the values $X, Z 1$ or $Z 2$, and the output value $Y(t)$ is calibrated for amplitude, mean or rms value depending on the used inverse converter $\mathrm{BC}$.

Another important conclusion can be drawn about pulsations at the output of the inverse converter BC. It is easy to show that if the time interval of the closure of switch SW2 is chosen equal to or multiple to the period of pulsations, then their component in the output value $Y(t)$ of the converter under consideration, i.e. the error due to the above pulsations is zero.

As a result, it is possible to use as a inverse converter $\mathrm{BC}$ a high-speed detector, i.e. the detector, which includes a low-pass filter with a very small time constant. The limiting case here is the use of a detector without a low-pass filter at all. For example, in order to calibrate the output value $Y(t)$ of the converter under consideration by means of average values, a full-wave rectifier can be used as the inverse converter $\mathrm{BC}$ [7].

Case 2. Consider the case where the combination of input and output values of the converter under consideration is the following: the input value $X=$ $X(t)$ and the output value $Y=Y(t)$ are not a constant, while the input values $Z 1$ and $Z 2$ are constant.

If the converters $\mathrm{CV}_{X}, \mathrm{BC}$ and $\mathrm{CI}_{1}$ do not change the shape of the curve of the quantities entering their 
inputs, i.e. scale converters, then in this case it is easy to obtain the transformation equation for the steady-state regime in the following form:

$$
Y_{\infty C P}=\frac{K_{X} Z 1 K_{Z !}}{Z 2 K_{Z 2} \beta} X_{C} \text {. }
$$

If a detector of amplitude, mean or $r m s$ values is used as converter $\mathrm{CI}_{1}$, then in this case the transformation equation for steady state has the form:

$$
Y_{\infty a(m, r m s)}=\frac{K_{X} Z 1 K_{Z !}}{Z 2 K_{Z 2} \beta} X_{a(m, r m s)},
$$

where the subscript for $Y_{\infty}$ and $X$ depends on the type of detector used, respectively. The requirements for the key switching time are the same: the closing time of switch SW1 must be equal to or multiples of the period of the change in the value of $X(t)$, and the closing time of switch SW2 is equal to the period of the change in the value of $Y(t)$.

If the detectors of amplitude, mean or rms values are used as converters $\mathrm{CV}_{X}$ and $\mathrm{BC}$, then the transformation equation for the steady-state regime has the form (3) with the only difference that the subscript for $Y_{\infty}$ depends on the type of converter BC, and the subscript for $X$ depends on the form of converter $\mathrm{CV}_{X}$. In this case, the switching time of switches SW1 and SW2 does not depend on the periods of variation of the values $X(t)$ and $Y(t)$. The requirements for the converters $\mathrm{CV}_{X}$ and $\mathrm{BC}$ relative to pulsations are the same as in the cases considered above.

Summing up the analysis of the generalized structural scheme of the converter under consideration with ideal blocks, we can say the following. The structure considered is a measuring converter with iterative additive correction of the conversion error. Due to this correction, the transmission coefficients of the blocks $\mathrm{CI}_{1}, \mathrm{CI}_{2}, \mathrm{CO}_{1}, \mathrm{I}, \mathrm{CO}_{1}, \mathrm{SH}, \mathrm{CO}_{2}, . ., \mathrm{CO}_{m}$, $\mathrm{BC}$, i.e. blocks of a direct circuit covered by a feedback loop, do not enter into the transformation equation for the steady-state regime (in static). However, the transmission coefficients of these blocks affect the nature of the transient process of setting the output value $Y(t)$, i.e. on its dynamic qualities.

This is due to the fact that the values of the transmission coefficients of the blocks mentioned above are included in the expression for determining the convergence condition for the correction process $(|Q|<1)$, and also for the expression for the condition of finite duration of this process $(Q=0)$. In addition, the dynamics of the converter under consideration is affected by the value of the input variable $Z 2 K_{Z 2}$.

Changing its dynamic properties, i.e. changing of the rate of convergence of the error correction process, as well as the stipulation for ensuring convergence, are a criterion when choosing the permissible limit for the change in the value of $Z 2$.

The range of variation of the input values $X$ and $Z 1$ is limited only by the dynamic range of the blocks that are part of the converter under consideration. If the output value of the converter under consideration $Y$ is variable, and none of the $\mathrm{BC}$ or $\mathrm{CI}_{1}$ blocks do not changes the shape of output value $Y$, i.e. these blocks are large-scale converters, the frequency of the change in the value of $Y$ is also due to the dynamic properties of the converter under consideration and must be selected, first, from the condition for ensuring the convergence of the error correction process, and, second, from the condition of ensuring the required speed of the converter under consideration.

In the case where the blocks $\mathrm{CV}_{X}, \mathrm{BC}$ and $\mathrm{CI}_{1}$ are detectors of amplitude, mean or rms values, and at the same time high speed of the converter under consideration is required, it is possible to use detectors that do not contain low-pass filters, with the appropriate matching of the switches closing times with the pulsation period. If it is necessary to allocate a constant component of $X$ from periodic interference, it is necessary to select the appropriate switching time of the switch SW1.

\section{CONCLUSION}

It can be concluded that the converter under consideration can be used as a precision controlled generator. In this case, the input value of the converter under consideration can be any of the values $X, Z 1$ or $Z 2$, and the output value $Y(t)$ is calibrated for amplitude, mean or rms value depending on the used inverse converter $\mathrm{BC}$. If the time interval of the closure of switch SW2 is chosen equal to or multiple to the period of pulsations, then their component in the output value $Y(t)$ of the converter under consideration, i.e. the error due to the above pulsations is zero.

As a result, it is possible to use as a inverse converter $\mathrm{BC}$ a high-speed detector, i.e. the detector, which includes a low-pass filter with a very small time constant. The limiting case here is the use of a detector without a low-pass filter at all. For example, in order to calibrate the output value $Y(t)$ of the converter under consideration by means of average values, a full-wave rectifier can be used as the inverse converter $\mathrm{BC}$.

The structure considered is a measuring converter with iterative additive correction of the conversion error. Due to this correction, the transmission coefficients of the blocks of a direct circuit covered by a feedback loop, do not enter into the transformation equation for the steady-state regime (in static). However, the transmission coefficients of these blocks affect the nature of the transient process of setting the output value $Y(t)$, i.e. on its dynamic qualities. 
This is due to the fact that the values of the transmission coefficients of the blocks mentioned above are included in the expression for determining the convergence condition for the correction process, and also for the expression for the condition of finite duration of this process. In addition, the dynamics of the converter under consideration is affected by the value of the input variable $Z 2 K_{Z 2}$.

Changing its dynamic properties, i.e. changing of the rate of convergence of the error correction process, as well as the stipulation for ensuring convergence, are a criterion when choosing the permissible limit for the change in the value of $Z 2$.

The range of variation of the input values $X$ and $Z 1$ is limited only by the dynamic range of the blocks that are part of the converter under consideration.

\section{REFERENCES}

[1] Yu. Tuz, Structural Methodsof Impruving Accuracy of Measuring Devices, manual, Kyiv. Vyshcha Shkola, 1976. (in Russian).
[2] I. Sergeyev, "Research and Development of Integrating Measurement Converters with the Iterative Additive Correction of Errors," Ph. D. (Engineering) Thesis, Kyiv Politechnical Institute, Kyiv, Ukraine, 1978. (in Russian).

[3] Yu. Tuz, and I. Sergeyev, "An iterative converter of time interval to the voltage," Measurement Equipment, no. 7, pp. 15-17, 1976. (in Russian).

[4] I. Sergeyev, "Analysis of the ADC with a dynamic integrator," Measurement Equipment, no. 6, pp. 38-40, 1976. (in Russian).

[5] I. Sergeyev, "Analysis of the Potentiation Digital-toAnalog Converter Without Accounting of Imperfection its Blocks," Electronics and Control Systems, no. 4(46), Kyiv: NAU, 2015. pp. 52-57.

[6] I. Sergeyev, "Measurement Converter which Uses an Iteratively Integrating Conversion Method," XIII Int. Conf. AVIA-2017, 19-21 April 2017: Kyiv, 2017. pp. 3.18-3.23.

[7] Patent 603,912 USSR, Yu. Tuz, and I. Sergeyev, G 06 G, 7/26, 05.12.78. bull. 15 (in Russian).

Received February 03, 2017.

Sergeyev Igor. Candidate of Science (Engineering). Assosiate Professor.

Educational \& Research Institute of Information and Diagnostic Systems, National Aviation University, Kyiv, Ukraine. Education: National Technical University “KPI”, Kyiv, Ukraine (1973).

Research interests: automation of technological processors, measurement transducers.

Publications: 210.

E-mail: sergeyevi@i.ua

I. Ю. Сергесв. Аналіз узагальненої структурної схеми ітеративно-інтегруючого вимірювального перетворювача

Розглянуто узагальнену структурну схему вимірювального перетворювача, що використовує ітератівноінтегруючий метод перетворення. Зроблено аналіз його рівняння перетворення та рівнянь похибок для двох випадків: перший - коли вихідна величина $Y=Y(t) є$ змінною, тоді як вхідні величини $X, Z 1, Z 2 \epsilon$ постійними, і другий - коли вхідні величина $X=X(t)$ і вихідна величина $Y=Y(t)$ є змінними, а вхідні величини $Z 1, Z 2$ постійні. Наведено основні вирази для розрахунку.

Ключові слова: узагальнена структурна схема; итеративно-інтегруючий метод перетворення; рівняння перетворення; інтегратор; ітеративна аддитивная корекція похибок; динаміка ітераційного процесу; сталий стан.

Сергесв Ігор Юрійович. Кандидат технічних наук. Доцент.

Навчально-науковий інститут інформаційно-діагностичних систем, Національний авіаційний університет, Київ, Україна.

Освіта: Національний технічний університет України «КПІ», Київ, Україна (1973).

Напрямок наукової діяльності: автоматизація технологічних процесів, вимірювальні перетворювачі.

Кількість публікацій: 210.

E-mail: sergeyevi@i.ua

И. Ю. Сергеев. Анализ обобщенной структурной схемы итеративно-интегрирующего измерительного преобразователя

Рассмотрена обобщенная структурная схема измерительного преобразователя, использующего итеративноинтегрирующий метод преобразования. Произведен анализ его уравнения преобразования и уравнений погрешностей для двух случаев: первый - когда выходная величина $Y=Y(t)$ является переменной, тогда как входные величины $X, Z 1, Z 2$ являются постоянными, и второй - когда входная величина $X=X(t)$ и выходная величина $Y=Y(t)$ являются переменными, а входные величины $Z 1, Z 2$ постоянны. Приведены основные выражения для расчета.

Ключевые слова: обобщенная структурная схема; итеративно-интегрирующий метод преобразования; уравнение преобразования; интегратор; итеративная аддитивная коррекция ошибок; динамика итерационного процесса; установившееся состояние.

Сергеев Игорь Юрьевич. Кандидат технических наук. Доцент.

Учебно-научный институт информационно-диагностических систем, Национальный авиационный университет, Киев, Украина.

Образование: Национальный технический университет Украины «КПИ», Киев, Украина (1973).

Направление научной деятельности: автоматизация технологических процессов, измерительные преобразователи.

Количество публикаций: 210.

E-mail: sergeyevi@i.ua 